\title{
Dedications and Status: Catullus 1 and Horace Epodes 1
}

\section{AVEN MCMASTER}

The first poem in Catullus' collection is a dedication poem that both programmatically introduces his poetry and presents it as a gift to his friend Cornelius: ${ }^{1}$

Cui dono lepidum novum libellum arida modo pumice expolitum?

Corneli, tibi: namque tu solebas

meas esse aliquid putare nugas

iam tum, cum ausus es unus Italorum

omne aevum tribus explicare cartis

doctis, Iuppiter, et laboriosis.

quare habe tibi quidquid hoc libelli

qualecumque; quod, <o> patrona virgo,

plus uno maneat perenne saeclo. ${ }^{2}$

Whom do I give a neat new booklet

Polished up lately with dry pumice?

You, Cornelius; for you always

Thought my trivia important,

Even when you dared (the one Italian) 
Unfold the whole past in three papyri-

Learned, by Jupiter, and laborious!

So take this mere booklet for what it's worth,

Which may my Virgin Patroness

Keep fresh for more than one generation.

It has long presented several issues for scholars, most notably Catullus' choice of dedicatee, the sincerity (or lack thereof) of that choice and his praise of the other writer, and the reading of the second-to-last line and its connection to the rest of the poem. In this article I propose that reading the poem as constrained by and participating in the larger context of elite gift-exchange and obligation in the Roman world helps point towards resolutions to these long-standing issues. I will then demonstrate that this focus on the problems of gift-giving also helps contextualize and motivate Horace's use of Catullus' poetry in his Epodes, by examining Epodes 1 and Horace's own strategies of poetic dedication.

Gift-exchange and the obligations it produces form one of the central frameworks for defining social bonds within Roman society and were part of how Roman poets constructed the world. This is most explicitly evident in the poets' references to "patrons" and benefactors, but it extends much further. The poets worked within a broad framework of social conventions and expectations which must be understood in order to see how their poetry uses and responds to the concepts associated with gifts, obligations, and generosity. Rome in the late Republic was a society built on asymmetrical reciprocal obligation. At the same time, social and political position was determined by prestige, dignity, and public image. This combination of factors resulted in tensions and concerns over status in the giving and receiving of gifts, favors, and 
services: in most cases, to give a gift or confer a favor was to claim a position of superiority, while to receive a gift or accept a favor was to admit to a position of inferiority and could therefore be potentially embarrassing or humiliating.

The first poem in Catullus' collection strongly foregrounds the issue of giving and receiving. ${ }^{3}$ It opens by asking who is a suitable recipient for Catullus' poetry and for his generosity: Cui dono lepidum novum libellum ("Whom do I give a neat new booklet," 1.1). This is a rhetorical question answered immediately by the poet, but it highlights the issue central to any dedication: who is the dedicatee and why, and what relationship does dedicating a poem or collection of poems establish between the poet and the dedicatee $?^{4}$ Cicero, in the De Officiis, ${ }^{5}$ says that there are two kinds of giving: unum dandi beneficii, alterum reddendi ("the first bestows a kindness, and the second repays it," 1.15.48), ${ }^{6}$ of which the former is optional, but the latter required. Since the poem begins by asking to whom the book should be given, it implies that the poet has free choice, and thus that the gift will be of the former type. This produces an initial impression of the poet as benefactor, in a position to bestow his generosity wherever he pleases, and thereby create an obligation on the part of the recipient. The emphasis on the quality of the gift (lepidum, expolitum) and its novelty (novum, modo) is appropriate in this context, since its purpose is to increase the value of the beneficium. Seneca says that in order to maximize the value of a gift and the gratitude felt by the recipient, one should give something rare, suitable to the recipient's taste and interests, not already possessed by the recipient, and enduring. ${ }^{7}$ The newness of Catullus' poetry book takes care of the first and third items in this list, while the second is covered by the lines describing Nepos' own literary interests. The last item is addressed in the final line, in Catullus' prayer that his poetry will endure long past his own or Nepos' lifetime. In this context the use of dono rather than do in the initial question is 
suggestive. Catullus uses donare only three other times in his poetry, and there seems to be a distinction in his usage between it and the simple dare. ${ }^{8}$ In his usage, donare seems to convey a greater sense of grandeur and formality than dare.

The immediate impression of Catullus as initiating a cycle of giving is modified, however, as the poem continues. A recipient is named, and the reasons for the choice are enumerated (1.3-7). Both Cicero and Seneca, in their works on benefits and duties, repeatedly emphasise the importance of choosing the recipient of beneficia very carefully and enumerate the qualities that should be looked for in a potential recipient. ${ }^{9}$ Cicero also stresses the importance of affection and friendship when deciding to give a beneficium to someone: de benivolentia autem, quam quisque habeat erga nos, primum illud est in officio, ut ei plurimum tribuamus, a quo plurimum diligamur ("When persons show us goodwill, our main obligation is to be generous most of all to the one who feels greatest affection for us," Off. 1.15.47). It is evident elsewhere in his poetry that Catullus has a similar attitude to Cicero and Seneca with regards to the importance of the structured exchange of beneficia, and he uses the associated language of amicitia throughout his poems to praise, exhort, rebuke, or condemn his friends, enemies, and lovers. ${ }^{10}$ Catullus differs from these authors in his valuation of the qualities that are desirable in one who is to receive his favors and affection. Instead of traditional Roman virtues such as those enumerated by Cicero and Seneca, ${ }^{11}$ the characteristics that interest Catullus are primarily those associated with his literary and aesthetic affiliations. In particular, some of his key terms of praise are venustus, lepidus, elegans, urbanus, bellus, and doctus. ${ }^{12}$ These terms are not alien to Cicero's own language, especially in his personal correspondence, in which he generally views them as desirable qualities, ${ }^{13}$ but they are not the characteristics that he considers important in judging the suitability of a potential recipient of beneficia, or even of a potential friend. ${ }^{14}$ It is in 
this that Catullus and his associates break with conventional Roman attitudes, not in their basic regard for the traditional Roman structures of amicitia and gift exchange. They substitute aesthetic belonging and acceptance for traditional morality, but maintain the conventional mechanisms for constructing and demonstrating their connections and judgements.

To return to Catullus' dedication poem, then, lines 3-7 outline the reasons that Catullus chose Nepos to receive this book: the services that Nepos has performed in the past for the poet, such as considering his "trivial works" (nugae) to be of importance and worth something within the literary community. This gift is therefore a requital, an act of gratitude, rather than an initiation of the cycle of gift exchange. ${ }^{15}$ Catullus is thus not eliciting gratitude but displaying it by giving or dedicating his book of poetry to Nepos. The situation we originally imagined is reversed, with Catullus demonstrating his obligation to, and even perhaps dependence on, Nepos. Instead of claiming a position of comparative power relative to Nepos, Catullus acknowledges Nepos' status as benefactor. This possible interpretation is supported by the deprecatory tone of Catullus' description of his book of poetry. ${ }^{16}$ It was conventional for the recipient of a beneficium to protest his inability ever to repay it adequately and to depreciate any requital he did make. ${ }^{17}$ This tone, and the fact that the poem concentrates on Nepos' actions rather than his intrinsic qualities, seems on the whole to favor interpreting it as a token of gratitude rather than an unsolicited gift. The conjunction namque in line 3 likewise introduces a reason for Catullus' choice of recipient, and while it does not abolish the freedom of his choice, it gently introduces the idea of a kind of obligation. However, the initial impression does not fully disappear, and the ambiguity may be deliberate; by suggesting both interpretations, Catullus could be moderating the explicitness of the status inequality generated by his expression of gratitude, thus lessening the potential damage to his own dignity. At the same time, he is able to use the aspects of the 
conventional workings of beneficia to his advantage, because he gains prestige from his relationship with Nepos one way or the other, having given the reasons why Nepos is either an appropriate recipient or a discriminating benefactor. In the end, Catullus can be deferential and complimentary and gain standing from his association with a man of good taste (which replaces the criterion of proper ethical judgement in more conventional circles), while maintaining enough ambiguity about the relationship between them to allow him to avoid unmistakeably taking on the role of lesser amicus.

Reading the poem in this way helps to clarify the corrupted penultimate line of the poem and strengthens the argument for emendation to o patrona virgo (1.9). Here we see a continuation of the delicate negotiation of position required by the act of dedication, as the emended phrase demonstrates one final strategy for deflecting any potential loss of status. According to the generally-accepted reading given by R. A. B. Mynors, Catullus turns at the end of the poem to address his patrona virgo, usually understood as a muse, asking her to help his poems endure for more than one saeclum. ${ }^{18}$ He reserves the term patronus to the end of his poem, thus giving it greater emphasis — and then denies it to Nepos, who might have seemed a potential recipient of the title, according to the logic of the poem. ${ }^{19}$ By naming another figure as patron, Catullus transfers much of the burden of gratitude expected in a dedicatory poem away from Nepos, the original addressee. Displaying dependence or gratitude towards a deity was much less problematic than doing so towards another Roman citizen. Catullus uses the language of clientela in connection with a goddess elsewhere in his poetry (34.1-2), where the puellae et pueri integri are said to be in fide of Diana, as if, according to C. J. Fordyce, she were their patron. ${ }^{20}$ There have been some critics, however, who are uncomfortable with the reading patrona and the sudden appeal to an unnamed goddess. Fordyce thinks that virgo is "curiously 
unexplicit” and prefers Bergk's emendation, qualemcumque quidem est, patroni ut ergo, suggesting that this gives the libellus "a patronus to speak for it-Cornelius himself. He, as Catullus has just said, is a figure in the world of letters and his name will ensure a future for the book in spite of its shortcomings." ${ }^{21}$ However, this analysis ignores the anxiety over position that has been apparent throughout the poem. It is impossible that Catullus would have called Nepos his patronus; they were far too close in status for that to be acceptable, unless it were in the technical sense. ${ }^{22}$ Yet there is no way to make the legal meaning work here-it would be far more intrusive than an appeal to an unspecified muse. ${ }^{23}$ The manuscript reading, with the emendation for the meter, is perfectly appropriate as a final tactic in Catullus' on-going effort to preserve his dignity and status, while maintaining his connections to a chosen circle of literary contemporaries.

In his first poem, therefore, Catullus recognised the potential problems of status involved in a dedicatory poem and so exploited the ambiguity of the act of giving to make the power relationship between himself and his dedicatee unclear. I want to turn now to examine one of his successors, Horace, and his approach to this problem in his early work. When Horace was composing his collection of iambic poetry, strongly influenced by Catullus but attempting to establish his own claim to originality in Latin poetry, he was even more aware of these same problems and the ambiguities of gift giving in a literary context. His situation was different from Catullus', however, both in terms of the degree of financial independence he had and in the political and social context of his work. Thus the strategies he employed to lessen the difficulties of dedicating his work to a powerful contemporary were correspondingly different.

Horace's Epodes 1, like Catullus 1, is clearly a dedication poem, but it is addressed to someone who is explicitly identified as the poet's benefactor. ${ }^{24}$ This poem, and by extension all 
the poems in the collection which it introduces, form a token of Horace's gratitude for Maecenas' generosity in the past. Horace must therefore carefully negotiate the issue of relative status, balancing his desire to be complimentary to Maecenas against his reluctance to reduce his own position too much. ${ }^{25}$ Ellen Oliensis sees this poem as opening with a "programmatic exercise in epodic hierarchy" which establishes the relative positions of poet and patron, and with a "gesture of deference [that] extends not only to his position in the hierarchy but to the very mettle of his manhood", ${ }^{26}$ as the poem continues, however, this subordination of Horace to Maecenas is problematized. ${ }^{27}$ While agreeing with the outlines of this reading, I think the mechanisms of Horace's negotiation of his position require more detailed examination, especially with reference to the example furnished by Catullus 1.

Horace's goal, and therefore his strategy, is not the same as Catullus' in his interactions with Nepos. Although it is not made explicit in the poem, the gap between Horace, Italian freedman's son, and Maecenas, close friend of Octavian and wealthy descendant of Etruscan kings, was enormous. It precluded the possibility of Horace trying to establish himself as the benefactor rather than the recipient, even in the constructed poetic fiction of friendship among equals. It also allowed Horace to acknowledge receiving generosity from Maecenas and to treat this as a mark of honor rather than degradation. ${ }^{28}$ Since Horace willingly admits his gratitude to Maecenas, the problem he faces is the possible perception that his relationship to Maecenas is based solely, or at least largely, on his hopes for material gain from his more powerful friend; connected to this is the possibility that he may be seen as writing poetry essentially for pay, with the gifts from Maecenas being rewards for his poetic production. Horace's main strategy, therefore, is to present the relationship between the two men as founded on affection and to emphasize his own emotional attachment to Maecenas. He raises the possibility that his desire 
for wealth and material rewards is the motivation for his support of Maecenas, only to dismiss it, and he attempts to redefine gratia in an affective, rather than material, sense.

The framework of amicitia is signalled immediately in the first apostrophe to Maecenas: ibis Liburnis inter alta navium, / amice, propugnacula ("You'll sail, dear friend . . among the galleons tall as fortresses" Epod. 1.1-2). ${ }^{29}$ In fact, the key word amice appears before Maecenas' actual name, introduced in the next clause: paratus omne Caesaris periculum / subire, Maecenas, tuo ("ready to take the load of danger Caesar bears / on your own shoulders [Maecenas]" Epod. 1.3-4). This not only serves a programmatic purpose, by prioritizing the theme of friendship, central to the book as a whole, but also emphasizes the connection between the poet and his addressee, which Horace wishes to be seen as primary. Also, the term amicus is, at least notionally, one used between equals, so by introducing it before he reveals the name (and therefore the exalted status) of his addressee, Horace immediately establishes a sense of parity between himself and Maecenas. The emotional aspect of the relationship is stressed in the following lines: quid nos, quibus te vita si superstite / iucunda, si contra, gravis? ("And what are we to do, since life is sweet for us / if you survive, and bitter if you die?" Epod. 1.5-6). This conventional protestation of devotion ${ }^{30}$ employs language familiar from love poetry, especially iucunda and gravis, the first a very Catullan epithet for the beloved, the second a traditional description of the pain and sorrow felt by the rejected or abandoned lover. It serves the dual purpose of both emphasizing Horace's affection for Maecenas by exploiting the emotional intensity of the language of love poetry and demonstrating the difference between the lives and characters of the two men. ${ }^{31}$

The emphasis on the friendship that Horace feels for Maecenas is continued a few lines later: 


\author{
feremus et te vel per Alpium iuga \\ inhospitalem et Caucasum \\ vel Occidentis usque ad ultimum sinum \\ forti sequemur pectore. (Epod. 1.11-14) \\ We'll bear. Across the ridges of the Alps \\ and the inhospitable Caucasus, \\ or to the furthest bay of all the Western seas \\ we'll follow you with fearless heart.
}

These lines have been compared to a similar passage in Catullus 11, in which the poet quotes the protestations of his friends Furius and Aurelius back to them: ${ }^{32}$

Furi et Aureli, comites Catulli, sive in extremos penetrabit Indos, litus ut longe resonante Eoa tunditur unda, sive in Hyrcanos Arabasve molles, seu Sagas sagittiferosve Parthos, sive quae septemgeminus colorat aequora Nilus, sive trans altas gradietur Alpes, 
Caesaris visens monimenta magni,

Gallicum Rhenum horribile aequor ultimosque Britannos, omnia haec, quaecumque feret voluntas caelitum, temptare simul parati ... (11.1-14)

Furius and Aurelius, Catullus' comrades, Whether he'll push on to furthest India Where the shore is pounded by far-resounding Eoan rollers,

To Hyrcania or effeminate Arabia, The Sacians or the arrow-bearing Parthians

Or those levels to which the seven-double Nilus gives color,

Or make his way across the towering Alps

To visit the memorials of great Caesar, The Gallic Rhine, those horrible woad-painted And world's-end Britons---

All this, whatever the will of Heaven above May bring, ready as you are to brave together ...

Horace, by his own admission in the previous lines, is no more suited to accompany Maecenas to battle in foreign lands than Catullus' friends seem to have been to carry out their extravagant 
promises. However, he is unsuited for such a task because of his essentially mollis ("soft") and imbellis ("unwarlike") nature, the cause and result of his poetic persona, not because he is insincere in his protestations of friendship. This is what necessitates the modifications to the humorously hyperbolic Catullan model that Horace offers in his poem. He uses the same friendship topos as Catullus, that of a willingness to travel to distant lands, but his choice of geography is significantly different. Instead of the exotic locales named by Catullus (India, Arabia, Britain), Horace lists the Alps, the Caucasus, and the western shores of the Mediterranean. David Mankin points out that all three of the areas that Horace names were potential arenas for war with external enemies instead of fellow Romans: Gauls and Germans across the Alps, Parthians by the Caucasus, and Spaniards in the west. This is in opposition to the civil war to which Maecenas is headed in the east, a part of the world that Horace fails to mention. ${ }^{33}$ Mankin believes that the "focus on 'trouble spots' of military concern distinguishes this context from many of the supposed parallels, in which the destinations include impossibly remote or even fabulous places." ${ }^{34}$ The choice of locales may also suggest that Horace wishes Maecenas were fighting in wars against externi rather than Romani.

There are stylistic differences between the two poems as well. ${ }^{35}$ In Horace's poem, the list is given in much simpler fashion, in one sentence of four lines, and the descriptions of the locations are less elaborate: the iuga of the Alps are modified by no adjective, the Caucasus by the plain inhospitalem, and the sinum only with ultimum $^{36}$ and Occidentis; as well, the word order is relatively straightforward, with no dramatic sound effects. In contrast, Catullus' catalogue, though also forming part of only one sentence, takes up eleven lines, and the language is as extravagant and exotic as the places that are described-Eoa, Hyrcanos, molles, sagittiferos, septemgeminus, horribile — and full of sound effects, such as the $n$ 's, $o$ 's, and $u$ 's of 
longe resonante Eoa / tunditur unda (11.3-4), the s's of seu Sagas sagittiferosve Parthos (11.6), and the $m$ 's and $n$ 's of monimenta magni (11.10). ${ }^{37}$ The tone of Catullus' poem is also strongly mocking and ironic, as shown in the deflating message that he asks his friend to convey, after all that buildup. The contrast between the two poems makes Horace's offer seem more realistic and more sincere than the exaggerated promises of Furius and Aurelius. The same effect results from Horace's modification of the generic conventions of the friendship topos that both writers employ here. In Catullus 11, the topos is used in the standard, hypothetical way: "you are my friends and would therefore accompany me anywhere." In the epode, however, "Horace uses it in a factual form: 'I will accompany you anywhere'; and this makes the topos relevant to the situation in hand, where Horace is stating that he will in fact accompany Maecenas." ${ }^{38}$ This reinforces the contrast between Catullus' version and Horace's and emphasizes the sincerity of the latter's offer. Nonetheless, the parallels between Furius and Aurelius on the one hand and Horace on the other, established so carefully through verbal and thematic allusion, stress his unsuitability for the journey on which he is embarking, thus demonstrating how deep his friendship must be, since he wants to accompany Maecenas anyway.

Further verbal references to Catullus' poetry in the epode underline the strength of Horace's feelings for Maecenas. One of the more obvious is satis superque ("enough and more") in line $31 .{ }^{39}$ The same phrase is found at Catullus 7.2, and satis et super is in line 10 of the same work, surely even in antiquity one of Catullus' most memorable poems, along with its companion piece, poem $5{ }^{40}$ The phrase recalls the intensity of Catullus' feelings for Lesbia and his insatiable appetite for her presence and her favor ${ }^{41}$ Horace likewise wants Maecenas' affection and favor (benignitas tua, line 31), but is more restrained: he can be and has been satisfied by what Maecenas has given him. He uses the connotations of the earlier poem and the 
whole complex of poems surrounding Lesbia to support and reinforce his argument and the emotion of his poem, but also as an ironic and witty contrast to his own situation. The allusion emphasizes Horace's own love for Maecenas and strengthens the emotional force of the piece.

The simile in lines 19-22 hints at Horace's desire to assert his independence from his generous patron, while at the same time emphasising the emotional attachment between them:

ut adsidens implumibus pullis avis serpentium allapsus timet magis relictis, non, ut adsit, auxili latura plus praesentibus.

just as the mother bird while guarding unfledged chicks fears most the serpent's glide when she has left the nest, although her presence could not be any help to them.

It is Horace who is being compared to the mother bird and Maecenas who is equivalent to the helpless chicks. This implies a reversal of the position of the protector and protected, although, according to Oliensis, Horace is an ineffective protector. ${ }^{42}$ She also connects the simile to the one used by Achilles in Iliad 9.32-4, in which the hero compares himself to a mother bird working to get food for her chicks and getting nothing for herself. ${ }^{43}$ Horace has replaced the content of Achilles' simile with "his own deferential blend," but the implied reversal of positions remains to remind us that the mother bird can figure not only helplessness but nurturing 
generosity in relation to her young. The simile may thus serve as an emblem, albeit highly compressed and imperfect, of Horace's characteristic career trajectory, from recipient of benefits to source. ${ }^{44}$ If the poet can be seen as in any way giving to Maecenas rather than accepting his generosity, it reinforces his argument that his connection with his patron is based on friendship, not expectation of material benefits.

In a similar vein, Horace's declaration that Maecenas has already sufficiently enriched him is part of an extended disavowal of excess:

non ut iuvencis illigata pluribus aratra nitantur mea, pecusve Calabris ante sidus fervidum Lucana mutet pascuis, neque ut superni villa candens Tusculi

Circaea tangat moenia.

satis superque me benignitas tua ditavit: haud paravero, quod aut avarus ut Chremes terra premam, discinctus aut perdam nepos. (1.25-34)

not that more bullocks should be yoked to pull my ploughs, not that before the Dogstar comes my flocks should leave Calabria and go to pasture in Lucania, 
nor that my gleaming villa high at Tusculum should touch the walls of Circe's son.

Your kindness has already given me enough and more. I shall not gather wealth

to bury in the earth, like stingy Chremes, or squander like some feckless fool.

This states Horace's favorite philosophical stance of moderation, which he developed much further in his subsequent poetry. It is not, however, an original idea, and would have been familiar to his readers from other philosophical and poetic works. ${ }^{45} \mathrm{He}$ acknowledges the need for a certain amount of wealth, but rejects any suggestion of continual acquisition, maintaining that once his modest needs have been fulfilled, he requires no further material reward from Maecenas. The phrase iuvencis .. . pluribus in line 25 is key to this contention, since it assumes that some, or even many, bullocks (and by extension ploughs, and by further extension acres of land) are necessary and desirable, but sets a limit to the number. This is also relevant to Horace's strategic self-positioning as motivated, in both his life and his poetic endeavors, by friendship rather than by obligation or greed. If he has already attained everything he wants materially, he stands in a position of relative independence, with no need to court Maecenas' favor. If he does attend on Maecenas, then, that attendance is motivated not by self-interest, but by gratitude and affection; the non ut of line 25 is one half of an adversative pair, and since it is not answered by any sed in the final part of the poem, the phrase that precedes it must be seen as the other alternative. Therefore, in tuae spem gratiae ("in hopes of pleasing you," 1.26) is, by implication, opposed to the material riches described in the last ten lines of the poem. Horace has constructed 
his poem in such a way as to exclude material rewards from his current relationship with Maecenas (though he acknowledges that they did play a role in their past interactions). ${ }^{46} \mathrm{We}$ have already seen that the relative positions of poet and patron are such that Horace can acknowledge his gratitude without significant loss of status, and the acknowledgement is certainly less degrading than the assumption that he acts out of impoverishment or greed—which explains Horace's insistence on the modesty of his desires and his rejection of both avarice and prodigality: the last ten lines of the thirty-four-line poem are devoted to this theme. Unless the reader accepts Horace's assertion of financial independence and contentment, his earlier protestations of affection may seem insincere. ${ }^{47}$ Though dedicated to Maecenas, this poem is intended for a wider audience. Therefore Horace aims his rhetorical strategies not so much at Maecenas, who could be expected to know his feelings due to their close association, but at this wider readership, who may impute more mercenary and less creditable motives for his attachment. ${ }^{48}$ Horace can accept admitting inferiority to, and partial dependence on, Maecenas but is not willing to lose his status and independence completely.

Looking at these two poems reveals that Catullus' first poem, as a dedication, foregrounds gift-giving as a poetic problem not only for his collection as a whole, but also for collections of poetry at Rome in the next generation. It brings to the fore the connection between poetry, generosity, and patronage. Horace's deployment of the nexus of relations among poet, patron, and readers to mitigate the problem of status builds on Catullus' inversion of conventional Roman ideals of liberalitas. The conceit of poetry as an item of exchange, a gift that is more valuable than material objects, is useful to Horace in articulating the contrast between the poet and the statesman, a common theme in his poetry. 
McMaster 18

Thorneloe University

amcmaster@laurentian.ca 
${ }^{1}$ It is of course not certain that the collection as we have it was organized in exactly this order by Catullus himself, but poem 1 must have been an introductory poem, whatever the precise collection it introduced. For discussion of the poem as an introductory poem, see F. Cairns, “Catullus I,” Mnemosyne 22.2 (1969) 153-158; T. P. Wiseman, Catullan Questions (Leicester 1969); K. Quinn, Catullus: The Poems, 2nd ed. (London 1996); J. Van Sickle "Poetics of Opening and Closure in Meleager, Catullus and Gallus," CW 75 (1981) 65-75; and M. B. Skinner, Catullus in Verona: A Reading of the Elegiac Libellus, Poems 65-116 (Columbus 2003).

${ }^{2}$ The edition used is K. Quinn, (above, n.1); the translations of Catullus' poetry are those of G. Lee, Catullus: The Complete Poems (New York 1990).

${ }^{3}$ See Sarah Culpepper Stroup, Catullus, Cicero and a Society of Patrons (Cambridge 2010), especially chapters 2 and 7, for a detailed and thoughtful discussion of the place of the text, in particular as a physical object, as an item of exchange in Catullus.

${ }^{4}$ C. Martin, Catullus (New Haven 1992) 122, states: "Poem 1, the dedication to Cornelius Nepos, is not simply personal, but programmatic: its opening phrase, Cui dono, 'To whom will I give,' introduces the theme of gift giving."

${ }^{5}$ In order to establish one set of contemporary standards against which the poetry of the late Republic and early Augustan period can be viewed, I use Cicero and Seneca to represent the philosophical ideals of the elite Roman society of the period; Seneca is of course a later author, but he uses and responds to philosophical writings of the earlier period. The philosophical works by Cicero and Seneca give advice on how to live the good and happy life. I have turned to these 
prose works for a framework for my discussion because they give a relatively clear picture of many aspects of the practice of gift-exchange as viewed by approximate contemporaries of the poets I am examining. In many ways, however, the information given by these texts is not essential to my argument; the concern about gifts, obligation, gratitude, and dependence are in the poems themselves, regardless of what is said by Cicero and Seneca. The poets I am discussing shared an educational and literary culture with Cicero and Seneca, which helped some of them to rise in elite society, and which tended to mask social difference within the context of literary production.

${ }^{6}$ This and all subsequent translations of Cicero's De Officiis are from P. G. Walsh, tr. Cicero: On Obligations (Oxford 2000); translations of his De Amicitia are from William Armistead Falconer, tr. Cicero: De Senectute De Amicitia De Divinatione. (Cambridge, Mass. 1923). ${ }^{7}$ Si arbitrium dandi penes nos est, praecipue mansura quaeremus, ut quam minime mortale munus sit ("If the decision about giving is in our own power we will seek above all to give things that will last, so that the gift will be as immortal as possible," Ben. 1.12.1); and munera non tam pretiosa quam rara et exquisita sint ("the gifts should not be chosen for their costliness, but rather because they are scarce and hard to find," Ben. 1.12.4). These and all subsequent translations of Seneca are from M. Griffin and B. Inwood, trs. Seneca: On Benefits (Chicago 2011).

${ }^{8}$ In poems 13,62 , and 101 . The first occurrence (13.12) is perhaps for variety, since dare is used in the preceding line, but it is used of a gift from a goddess, however humorous the context may be. In the second passage (62.23), donare is used of Hesperus giving the bride to the bridegroom in marriage, while in the third (101.3), Catullus is giving gifts to his brother's ashes; both 
contexts are formal and somewhat ritualistic. As well, dō has less weight metrically than dōnō, an important consideration for Catullus.

${ }^{9}$ See especially Cic. Off. 1.14.45-1.15.46 and 2.20.69; and Sen. Ben. 4.9.2 and 4.11.1.

${ }^{10}$ See, for example, poems 12, 13, 14, 28, 29, 47, 49, and 65.

${ }^{11}$ Cicero lists modestia, temperantia, . . i iustitia ("moderation, self-control, and justice," Off.

1.15.46) as the most important virtues to look for in a potential recipient; Seneca says he would choose to bestow beneficia on a virum integrum, simplicem, memorem, gratum, alieni abstinentem, sui non avare tenacem, benevolum ("a man who is upright, candid, mindful of obligations, and grateful, who keeps his hands off another's property but is not greedily possessive of his own," Ben. 4.11.1).

${ }^{12}$ For a detailed examination of Catullus' vocabulary and its relation to Cicero's terminology of approval and disapproval see B. A. Krostenko, Cicero, Catullus, and the Language of Social Performance (Chicago 2001). D. O. Ross (Style and Tradition in Catullus (Cambridge, Mass. 1969) also discusses the language of urbanitas in the polymetrics (104-12 especially).

${ }^{13}$ See, for example, Cic. Att. 4.8.2, Quint. 1.3.3, and Fam. 7.32.3, 3.8.3, and 7.15.2.

${ }^{14}$ According to Cicero's De amicitia, friendship can exist only between good men qui ita se gerunt, ita vivunt, ut eorum probetur fides integritas aequitas liberalitas, nec sit in eis ulla cupiditas libido audacia, sintque magna constantia ("Those who so act and so live as to give proof of loyalty and uprightness, of fairness and generosity; who are free from all passion, caprice, and insolence, and have great strength of character" 5.19). There are other important considerations: sunt igitur firmi et stabiles et constantes eligendi ("We ought, therefore, to choose men who are firm, steadfast and constant" 17.62) and simplicem praeterea et communem 
et consentientem, id est, qui rebus isdem moveatur, elegi par est (" Moreover, the right course is to choose for a friend one who is frank, sociable, and sympathetic - that is, one who is likely to be influenced by the same motives as yourself" 18.65).

${ }^{15}$ The poem also highlights the characteristics that make Nepos a worthy recipient of Catullus' benefaction: his literary judgement (tu solebas / meas esse aliquid putare nugas 1.3-4) and the quality of his accomplishment (doctis . . et laboriosis 1.7). To mark these as the criteria for Catullus' decision to give his book to Nepos is to signal a deviation from traditional Roman standards, and this contrast is made more striking by its juxtaposition with the normal, expected, and solidly traditional Roman institution of beneficia.

${ }^{16}$ In his use of the term libellus for his book $(1.1,1.8)$ and the phrases "meas ... nugas" (1.4) and "quidquid hoc libelli / qualecumque" (1.8-9).

${ }^{17}$ Cic. Off. 2.20.70 and Sen. Ben. 2.24.4.

${ }^{18}$ See R. A. B. Mynors, C. Valerii Catulli Carmina (Oxford 1972). Also, A. M. Keith, Propertius: Poet of Love and Leisure (London 2008) 51, points out that patrona virgo builds on the allusion to Meleager's introduction to his Garland found in the opening lines: "In dedicating his polymetrics to Cornelius Nepos, Catullus closely reworks the opening couplet of the poem that prefaced Meleager's Garland (AP 4.1.1-2=Meleager1.1-2 Gow-Page): 'Dear Muse, to whom do you bring this song, rich in fruit of every kind, or who constructed this garland of songmakers?' In addition to the Meleagrian echo in his opening lines, Catullus transmutes the epigrammatist's 'dear Muse' into the 'maiden patroness' (patrona uirgo, Cat. 1.9) he invokes at the close of his lyric dedication." 
${ }^{19}$ See Cairns (above, n.1) 158: "Catullus in his replacement of Nepos by his Muse at the end of the poem is ... showing that the dedicatee was not his patron."

${ }^{20}$ C. J. Fordyce, ed. Catullus (Oxford 1968) 87.

${ }^{21}$ Fordyce (above, n.20) 87.

${ }^{22}$ The only other appearance of the word in the Catullan corpus (49.7) does not constitute evidence against this contention, since there Catullus uses the word in its technical legal sense of pleader or advocate. In any case, Cicero is omnium patronus, which effectively nullifies any perception of real inferiority that might conceivably linger.

${ }^{23}$ Quinn (above, n.1) 90 notes that "C[atullus] unlike Horace does not specify which muse he means, but then neither does Homer-or Meleager; to do so here might overdo the mock solemnity which invests the genuine feeling latent in this prayer"

${ }^{24}$ B. K. Gold, ed. Literary and Artistic Patronage in Ancient Rome (Austin 1982) 119-20, states: "Epodes 1 is in most ways a highly traditional and typical poem from client to patron ... the poem is, in many ways, a perfect symbolization of the proper kind of attitude toward a patron who is regarded with affection." But this raises the question of what type of relationship between Horace and Maecenas is demonstrated or described by the poem; Gold herself notes that there are aspects of the poem that seem to present Horace as "the strong member of the pair" (120). F. Cairns, Generic Composition in Greek and Latin Poetry (Edinburgh 1972) 11 classes the poem as an excusatory propemptikon, but sees the section starting at line 23 as introductory and dedicatory in function: "Epode 1 is the prologue to a book of epodes and so will necessarily have the functions of a prologue, its main function being programmatic, to display Horace as an epodic poet ... the secondary prologue function of 23ff. is dedicatory. The address to Maecenas 
at 4 is a dedication of the book of epodes to him, and Horace returns to Maecenas in his role as dedicatee in this last section of the epode" (142-43).

${ }^{25}$ R. L. B. McNeill, Horace: Image, Identity, and Audience (Baltimore 2001) 30, supports the assertion that Horace found the position of recipient of Maecenas' favor problematic: "it might be denied that the inequalities of the patron-client relationship required any sort of response at all. One of the duties of a cliens was to publicize the favors and other noteworthy accomplishments of his patron; consequently, it has been argued that clients had to accept openly their inherently inferior status. But Horace does not fit this model. Although he is careful to express his gratitude to his patron for his friendship, support, and other beneficia, he only implicitly acknowledges any subordination and does his best to confuse the issue with conflicting images of himself as Maecenas's friend and chosen companion. . . There is certainly no open acceptance of the relationship's uncertainties here but a definite attempt to present himself to better advantage." E. Oliensis, Horace and the Rhetoric of Authority (Cambridge 1998) 81, gives a close analysis of the opening lines of the poem which demonstrate its foregrounding of the subordinating relationships between Augustus, Maecenas, and Horace, but she also points out that this is not an unproblematic subordination: "Horace is not, after all, perfectly comfortable with the subordinate status displayed in the opening lines of his first epode" (82).

${ }^{26}$ Oliensis (above, n.25) 80-82.

${ }^{27}$ Oliensis (above, n.25) 82-84.

${ }^{28}$ Oliensis (above, n.25) 80 in fact suggests that Horace views the relationship between himself and Maecenas as an essential part of the stabilization of Roman life after the civil wars: "his 
subordination to Maecenas appears to be an instance of the kind of coupling which holds Roman society together."

${ }^{29}$ This and all subsequent translations of Horace are those of D. West, tr. Horace: The Complete Odes and Epodes (Oxford 1997).

${ }^{30}$ For the topos and Horace's modifications to it in this poem, see Cairns 1972 (above, n.24) 141.

Cf. also Tibullus 1.7 and Propertius 1.6. E. Oliensis, "The Erotics of Amicitia: Readings in Tibullus, Propertius, and Horace," in Roman Sexualities eds. Judith P. Hallett and Marilyn B. Skinner (Princeton 1997)152, points out the intersection of the language and actions of the client and the lover: "In the pursuit of their disparate goals, the client and the lover are represented as displaying similar virtues (constancy, discretion, eloquence) and encountering comparable obstacles (the machinations of rivals, the fickleness of patron or beloved)." The use of language from love poetry here thus can be seen to reflect the potential similarity of the subordination of the lover and the client. This similarity is later exploited by Ovid, who talks about winning a girl by officium at Ars Amatoria 2.177-232.

${ }^{31}$ Gold (above, n.24) 119 sees this as a conventional expression of loyalty from client to patron, but the parallels with Catullus 11 suggest that Horace wishes to display friendship here, not obligation or duty.

${ }^{32}$ Cairns (above, n.24) 99 relates this to a friendship topos: "the concept that the willingness to accompany a friend anywhere is a proof of friendship."

${ }^{33}$ D. Mankin, ed. Horace: Epodes (Cambridge 1995) 53-54.

${ }^{34}$ Mankin (above, n.33) 54.

${ }^{35}$ See L. C. Watson, A Commentary on Horace's Epodes (Oxford 2003). 
36 This is perhaps a direct allusion to Catullus 11.

${ }^{37}$ Quinn (above, n.1) 127 notes that Longa resonante is also a translation of the Homeric $\pi \circ \lambda u ́ \varphi \lambda o 1 \sigma \beta o \varsigma$, which adds to the grandiose feel of the passage.

${ }^{38}$ F. Cairns, "Virgil Eclogue 1.1-2: A Literary Programme?” HSPh 99 (1999) 141.

${ }^{39}$ According to H. Hierche (Les Épodes d'Horace: Art et Signification [Bruxelles 1974] 117), satis superque is a colloquial expression, and super in an adverbial sense is not found in Horace's odes.

${ }^{40}$ Poems 5 and 7 are cited by Ovid (Am. 1.8.58) and Martial (6.34.7, 11.6.14, 12.59.3). See E. T. Merrill, Catullus (Cambridge, Mass 1893).

${ }^{41}$ Note especially the force of vesano in line 10 of Catullus' poem, for which see Quinn (above, n.1).

${ }^{42}$ Oliensis (above, n.25) 83.

${ }^{43}$ Oliensis (above, n.25) 83-84.

${ }^{44}$ Oliensis (above, n.25) 84

${ }^{45}$ Its best-known expression is Aristotle's doctrine of the mean, most clearly seen in the Nicomachean Ethics. Epicureanism also taught that one should be content with the simple life. See N. W. Dewitt, “Epicurean Doctrine in Horace,” CP 34.2 (1939) 127-134.

${ }^{46}$ Oliensis (above, n.25) 84 points out that 'the perfect tense of ditavit, which locates Maecenas' act of generosity in the past and its continuing effects in the present, also helps shield Horace's behavior in this poem from the charge of materialism."

${ }^{47}$ Some critics have indeed felt that Horace protests too much about his pure motives. C. C. Mendell, Latin Poetry: The New Poets and the Augustans (New Haven 1965) 130, states: "He 
insists overmuch that it is not for mercenary reasons that he would go, and more than a third of the epode is occupied with the assurance that Maecenas has already given him ample rewards and that he desires no more" and this "does not present Horace in a particularly pleasant light." ${ }^{48}$ Here I am again using Oliensis' concept of "overreaders," the potential audience(s) other than the addressee. Other than Maecenas and Augustus, Horace's overreaders, as Oliensis (above, n.25) 7 states, "typically include Horace himself (Horace is always situated as an accomplished and interested overreader of his own poems), the reading public (including especially Horace's invidious critics, whether fictitious or actual), and more and more, the audience of posterity." 